\title{
PUSH FACTORS OF COMMUNITY PARTICIPATION IN THE MANAGEMENT OF WASTE BANK IN THE CITY OF SURAKARTA, CENTRAL JAVA PROVINCE, INDONESIA
}

\author{
Pambudi Yonathan Suryo*, Sudaryantiningsih Cicik \\ Environmental Engineering Study Program, University of Kristen Surakarta, Indonesia \\ *E-mail: ysp@uks.ac.id
}

\begin{abstract}
This study aims to determine the influence of internal and external factors on community participation in the management of the waste bank. The method used in this research is descriptive quantitative with the cross-sectional approach. The population of the research is a community of Surakarta in five sub-districts namely Serengan sub-district, Jebres subdistrict, Pasar Kliwon sub-district, Banjarsari sub-district, and Laweyan sub-district. The sample of the research is determined based on the random probability sampling with the Lemeshow method in order to obtain the minimum sample amount of 96 research sample. The amount of sample studied in this research is 125 respondents/head of household in five sub-districts in Surakarta. The data analysis technique used in this research is descriptive statistics and multiple linear regression test using SPSS software aid program to understand the influence of internal factors consisting of age, education, and gender, and the influence of external factors consisting of counselling, the activeness of environmental cadres, and the economic motivation of community of Surakarta against the community participation in the management of waste bank in Surakarta. The result of the research shows positive influence either internal factor consisting of age, education, and gender, and external factor consisting of access to information, the activeness of environmental cadres, psychological motive, social motive, economic motive against the community participation in the management of waste bank in Surakarta.
\end{abstract}

\section{KEY WORDS}

Community, participation, waste management.

Population growth, consumption pattern changes, and community's lifestyle in various cities especially in major cities in the world have improved the amount of heap, type, variety and characteristics of the waste. Most of the time, waste of urban area in developing countries are poorly managed. The research conducted by Mombon and Birgiwa (2017) state that there is a lot of waste poorly managed in the developing countries, the waste is often thrown out to the edge or side of the road, river bank, and open land. This becomes one of the challenges to create a healthier environment for the sake of the health and welfare of the community. Most of the cities in developing countries often lack the financial resources to provide adequate urban infrastructure for solid waste or waste management

As a developing country, Indonesia is facing the same issue as other developing countries in the world. In the case of domestic the solid waste or waste management, the government of Indonesia has a set of rules related to waste management, namely the Law of the Republic of Indonesia Number 18 of 2008 on Waste Management. In Article 28 Paragraph 1 of Law of the Republic of Indonesia Number 18 of 2008 on Waste management, it is stated that "community can participate in the waste management organized by the Government and/or local government." It means that the community participation in the waste management is required for the realization of a clean, healthy, organized and picturesque environment. One of the actual participations of the community in the case of waste management is the establishment of a waste bank.

Ministry of Environment and Forestry of the Republic of Indonesia (KLHKRI) stipulate waste bank program. This program is one of the assessment instruments for "ADIPURA" award. It is an award given by the central government to the cleanest and most organized city in Indonesia. The assessment is conducted not only on the cleanliness appearance in 
general but also on how the local government organizes their community in promoting the environmental health. The government of Indonesia has targeted that in 2014 all cities in Indonesia should have at least 5 units of waste banks to reduce the waste production in the surrounding area. The waste bank is a waste management program involving the community as the effort to increase the community participation independently by utilizing waste of economic value.

Waste bank management is similar to the management of the ordinary bank, however, in the waste bank the customer will not save their money but the household waste that can still be utilized. The result of the collection of sorted waste will be sold by the the administrator to the handicraft manufacturer of waste or to the waste collector. The profit will be collected and divided proportionally to each customer and every transaction will be recorded by the officer in the customer's account book. The waste bank is established based on the public concern on the environment which is filled with organic and inorganic waste. The increasing amount of waste will cause a lot of issues. Thus, it requires such processing in order to utilize the waste and turn it into useful materials. The waste management through waste bank system is expected to be able to help the government in managing the waste and improving the economy of the community (DLH municipal Surakarta, 2016).

The participation of the community of Surakarta in reducing household waste, one of which is the establishment of the waste bank. Since the issuance of the Regulation of Surakarta City Number 3 of 2010 concerning Waste Management, and Regulation of Surakarta City Number 2 of 2016 about the prevention and improvement of the quality of slum housing, the government of Surakarta keep promoting the establishment of the waste bank. The promotion of this waste bank, according to the data from the Environment Agency of Surakarta, dated February 2, 2016, there are about 75 community-based of waste banks scattered throughout Surakarta. They are divided into five sub-districts namely Banjarsari Sub-district (21 waste banks), Laweyan Sub-district (13 waste banks), Serengan Sub-district (18 waste banks), Pasar Kliwon Sub-district (7 waste banks), and Jebres Sub-district (16 waste banks). These five sub-districts in Surakarta have established a number of waste banks that vary and spread in each Ward (DLH Municipal Surakarta, 2016).

The research conducted by Artiningsih et al (2012) that examine the predisposing factors such as age, gender, and level of education against the participation in household waste management with case study in Sampangan and Jomblang, Semarang, show that most of the waste management is conducted by the community with low-level education background and those who work as self-employed, entrepreneur and housewife. A research conducted by Tanuwijaya (2016) examines the influence factors of community participation in waste management through a waste bank of Pitoe Jambangan Surabaya. The research shows that there are some factors that psychologically influence the community participation in waste management such as 1) psychology motive, 2) social motive, 3) religious motive, 4) economic motive, and 5) political motive.

The research on the waste management was conducted by Rachman et al (2016) on waste bank management in Karang Joang village, Balikpapan, which processing solid waste into compost. It is known that the activity of collecting and processing waste through the waste bank in village-scale can give economic value and can be turned into a business opportunity for some of the village members. This activity will improve the community's welfare and support the government program to reduce the amount of unemployment and poverty. Data collection technique in the research conducted by Rachman et al is through the distribution of a questionnaire to 500 residents and interviewed 5 housewives, as well as 1 owner of a grocery store.

Based on the background mentioned above, the researcher aims to conduct a research similar to a research conducted by Artiningsih et al (2012), and Tanuwijaya (2016) by combining several explanatory variables added to this research such as 1) What is the influence of internal and external factors on the community participation in the the waste management in Surakarta; 2) looking for the influence either partial and simultaneous between internal factors such as: age, education, gender and external factors such as: access to information, the activeness of environmental cadres, psychological motive, social 
motive, economic motive on the community participation in the waste management in Surakarta.

This research aims to describe the influence of internal factors such as; age, education, gender, and external factors such as access to information, the activeness of environmental cadres, psychological motive, social motive, economic motive on the community participation in the waste management in Surakarta. On the other hand, this research also aims to understand how the influence of internal factors such as age, education, gender and external factors such as: access to information, the activeness of environmental cadres, psychological motive, social motive, economic motive on the community participation in the waste management in Surakarta.

\section{THEORETICAL FRAMEWORK}

Based on the theoretical framework shown above, the proposed hypotheses are as follows:

There is partial influence between age, education, gender, access to information, the activeness of environmental cadres, psychology, social, and economy on the community participation in the waste management in Surakarta.

There is simultaneous influence between age, education, gender, access to information, the activeness of environmental cadres, psychology, social, and economy on the community participation in the waste management in Surakarta.

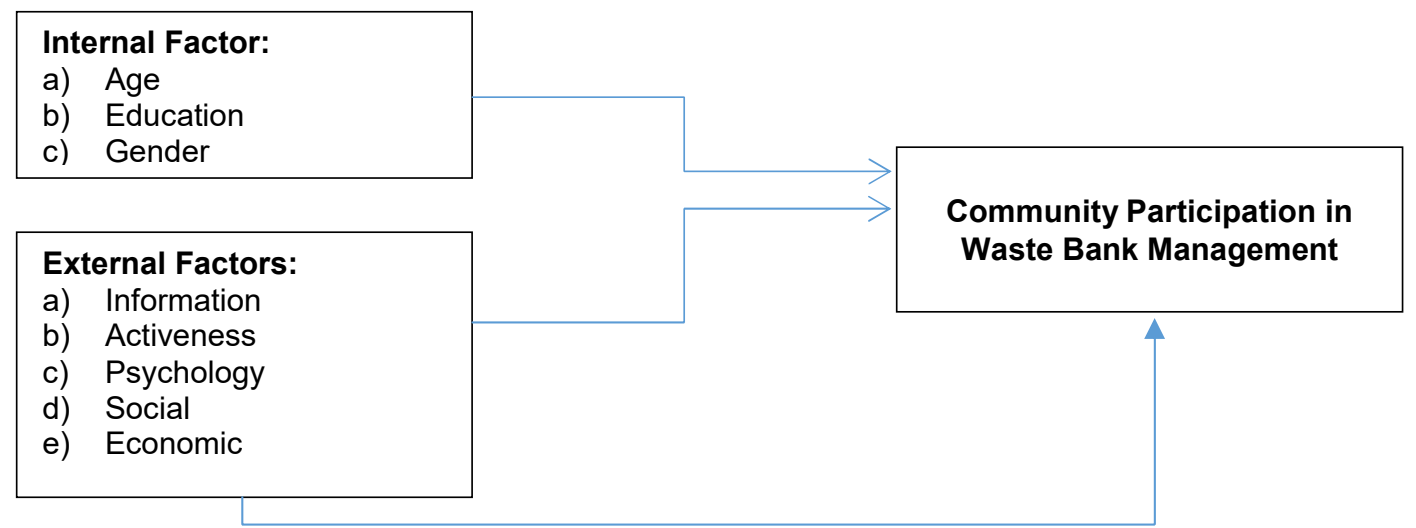

Figure 1 - Research Frame of Reference

\section{METHODS OF RESEARCH}

This research is a quantitative descriptive research with cross-sectional approach. Data collection technique is conducted by distributing the questionnaire to the community in Surakarta in five sub-districts namely: Serengan sub-district, Jebres sub-district, Pasar Kliwon sub-district, Banjarsari district, and Laweyan sub-district. The sample is determined based on random probability sampling with the Lemeshow method in order to obtain the minimum sample amount of 96 respondents. The data analysis technique used in this research is descriptive statistics, chi-square test, and multiple linear regression test using SPSS software aid program to understand the influence of internal factor consisting of age, education, and gender, and the influence of external factor consisting of counselling, the activeness of environmental cadres, and the economic motivation of community of Surakarta against the community participation in the management of waste bank in Surakarta. as follows:

The determination of research simple based on Lemeshow (Arikunto, 2016) theory is

$$
n=1 / 4\left(\frac{Z a / 2}{E}\right)^{2}
$$




\section{Description:}

$N$ - Number of samples;

$Z$ - Number indicating the deviation of a variable value from the mean count in the certain standard deviation;

E - Error.

The value of $\alpha$ (level of significant) used in this research is 0.05 . It is expected that the amount of error in the sample use (sample error) not more than $10 \%$. From the above formula, the number of samples can be determined as follows:

$$
\begin{gathered}
n=1 / 4\left(\frac{Z 0.05 / 2}{0.10}\right)^{2} \\
n=1 / 4\left(\frac{1.96}{0.10}\right)^{2} \\
n=96.04
\end{gathered}
$$

The number of samples from the above calculation is 96.04 respondents. Thus, in order to be the representative of the population then the required minimum sample is 96.04 respondents. In this research, 125 respondents are determined as the sample in order to make the number of respondents in each sub-district to be represented proportionally. Thus, the sample taken in each sub-district will be 25 people/Head of Household. This number is estimated to represent the population from 5 sub-districts in Surakarta.

\section{RESULTS AND DISCUSSION}

The partial test result of the push factors influence of the community participation in the management of the waste bank is discovered from the test result as follows:

\begin{tabular}{|c|c|c|c|c|}
\hline \multirow{2}{*}{\multicolumn{2}{|c|}{ Model }} & Standardized Coefficients & \multirow{2}{*}{$\mathrm{t}$} & \multirow{2}{*}{ Sig. } \\
\hline & & Beta & & \\
\hline \multirow{9}{*}{1} & (Constant) & 8.201 & 4.757 & .000 \\
\hline & Age & -.036 & -.514 & .608 \\
\hline & Gender & .149 & 2.166 & .032 \\
\hline & Education & -.170 & -2.409 & .018 \\
\hline & Access to Information & .381 & 3.872 & .000 \\
\hline & Activeness & -.146 & -1.654 & .101 \\
\hline & Psychology & .222 & 2.539 & .012 \\
\hline & Social & .235 & 2.568 & .012 \\
\hline & Economic & -.204 & -2.964 & .004 \\
\hline
\end{tabular}

Table 1 - Partial Test Result of Push Factors Influence of the Community Participation in the Management of Waste Bank in Surakarta

As it is known from Table 1 above, the age factor does not affect the participation of the community in the management of the waste bank. Gender, education, access to information, the activeness of environmental cadres, psychological, and economic factors have significant influence. The partial test result can be used in the estimation model as follows:

\section{Participation $=8.201-0.036$ Age +0.149 Gender -0.170 Education +0.38 Information -0.146 Activeness + 0.222 Psychological+0.235Social - 0204Economy.}

Constant shows that the constant value indicating the factors encourage the community participation in the management of waste bank by 8.201. This number shows that the community participation in the waste management exists. Although, there is no age, gender, education, information, activeness, psychological, social and economic factors.

Meanwhile, the age coefficient of 0.036 is a negative value indicating that the increasing in age will decrease the level of participation of the respondents. However, this 
doesn't significantly influence $(p>0.05)$ the community participation in the management of the waste bank. This research result is in line with the research conducted by Beni et al (2014) who state that age factor does not influence the level of community participation in the waste management.

The gender shows the coefficient value of 0.149 . The participation of women is higher than the man in the management of the waste bank. The reason is probably that housewives have more time at home and do the waste management in village level comparing to men who often spend most of their time outside the home to work. However, gender variable does not influence $(p>0.05)$ the respondents' participation in the waste management.

The research conducted by Beni et al (2014) on the gender variable also shows the same result. He concludes that gender does not influence the level of community participation in the waste management. Similar to the research conducted by Maulina (2012) who conclude that there is no influence from gender related to waste management. However, in Maulina's research, it is stated that the role of housewives is higher compared to the men's role in the participation in waste management.

Education coefficient value of -0.170 is the negative value indicating that higher education will cause lower interest of the respondents to participate in the management of the waste bank and it has significant influence $(p<0.05)$. It means that the community with lower educational background tends to be more active in participating in the management of a waste bank. The reason is that the community with the lower educational background will automatically think that waste bank will improve their life standard and welfare. In line with the research conducted by Beni et al (2014) who conclude that education significantly affects the level or participation in the waste management. Similarly, the research conducted by Maulina (2012) shows that the level of education affects the participation of the respondents in the waste management.

Access to information shows how often the community will get beneficial information about waste bank or information on the waste management. The coefficient value of 0.381 shows that the more information about the benefit of the waste bank given to the community, the higher the level of community participation in the management of the waste bank. It gives significant influence $(p<0.05)$. The research result conducted by Maulina (2012) shows that access information through socialization has a significant effect on the level of community participation in the waste management.

The activeness of environmental cadres has negative value but it does not significantly affect the community participation in the management of the waste bank. The result conducted by Maulina (2012) shows that the activeness of environmental cadres does not affect the level of community participation in the waste management. Contrary to the research conducted by Tanuwijaya (2016) who state that environmental cadres plays an important role and be a factor that encourages the community to participate in the activity in the waste management of the waste bank. It means that the activeness of environmental cadres has a significant role to encourage the community to participate in the management of the waste bank.

Psychological factor with coefficient value of 0.226 shows that higher psychological factor (achievement and self-satisfaction motives) will improve the community participation in the management of the waste bank. Psychological factor in the research conducted by Tanuwijaya (2016) is shown in the motives of achievement and self-satisfaction because the environment will be cleaner. That these two things are the psychological factors that have the influence to encourage the community to participate in the management of the waste bank.

The social factor with the coefficient value of 0.235 shows that higher social factor will improve the community participation in the waste bank. This factor has significant influence $(p<0.05)$. According to Asteria (2016), social factor such as the activity of mobilizing women is one of community-based society empowerment models with a gender perspective. As a social model, women will be able to mobilize individual and community to actively participate in the environmental management. Women can be the agent of change in the environmental management in the city. The socio-economic conditions of the community also influence the 
number and type of waste produced. Higher socioeconomic status of a community, because of sophisticated lifestyle, will generate more waste with different types (Suyanto, 2015).

Economic factor has the coefficient value of -0.204 shows that higher economic status of a community will decrease the community participation in the waste bank. Economic factors have significant influence $(p<0.05)$ on the community participation in the management of the waste bank. Based on the result of observation and interview in the field, the reason of the lower participation is because most of the respondents with higher economic status prefer to sell their recyclable waste directly to the collector rather than to the waste bank. Furthermore, respondents with the busy schedule usually do not have enough time and do not want to be bothered by directly participating in the social activities in their surroundings including the management of the waste bank.

The simultaneous test result of push factors of the community participation in the management of waste bank can be explained based on the result of $F$ test in Table 2 below:

Table 2 - The Simultaneous Test Result of Push Factors of the Community Participation in the Management of Waste Bank

\begin{tabular}{|c|c|c|c|c|}
\hline Sum of Squares & df & Mean Square & F & Sig. \\
\hline 333.803 & 8 & 41.725 & 12.610 & $.000^{\mathrm{b}}$ \\
\hline
\end{tabular}

Based on the data processing, it can be seen that the $F$ value of 12.610 with $P=0.000$ at the significant level $\alpha=5 \%$ significant $p<0.05$. Thus, it can be concluded that simultaneous factors such as age, sex, education, access to information, the activeness of environmental cadres, psychology, and economic significantly influence the community participation in the management of a waste bank.

The influence shows that the inherent factors in the individual influenced by the internal factors such as age, gender, or the level of education and external factors that directly or indirectly influence the individual in his or her activity to participate in the management of a waste bank.

\section{CONCLUSION AND SUGGESTIONS}

There is the partial influence of internal factors consisting of age and level of education and external factors such as information, psychological, social, and economic factors in encouraging the community participation in the management of the waste bank. Meanwhile, age factor and the activeness of environmental cadres do not have influence in encouraging the community participation in the management of the waste bank.

There is the simultaneous influence of internal factors consisting of age and level of education and external factors such as access to information, the activeness of environmental cadres, psychological, social, and economic factors in encouraging the community participation in the management of the waste bank.

Based on the research result, the researcher suggests that:

The government of Surakarta should develop a lot better method for the management of waste bank by involving the community and related stakeholders. Socialization on the management of waste and waste bank to the community should also be improved, so that the community of Surakarta will be more aware of the management of household waste through the waste bank.

The activeness and capacity of the environmental cadres and waste bank officer should be improved. Thus, intensive monitoring should be conducted by the government.

The government should encourage and improve the community participation in the management of green waste through $3 R$ principles (Reduce, Reuse Recycle). Thus, the possibly implemented strategy is improving the role of green community, the waste bank officer, and cadres/members of Family Welfare Movement (PKK) through the improvement of capacity, supporting facilities, and award in accordance with the target and achievement of the activities implemented in the field. 


\section{REFERENCES}

1. Artiningsih, N.K.A., Sudharto, H.P., Syafrudin. 2012. Peran Serta Masyarakat Dalam Pengelolaan Sampah Rumah Tangga, Studi Kasus di Sampangan dan Jomblang, Kota Semarang. Jurnal IImiah UNTAG, Pp. 107-114.

2. Asteria, D. \& Heru, H. 2016. Bank Sampah Sebagai Alternatif Strategi Pengelolaan Sampah Berbasis Masyarakat di Tasikmalaya. Jurnal Manusia dan Lingkungan. Vol. 23, No. 1 Maret 2016. Pp: 136-141.

3. Harningsih, T. 2010. Peran Gender Dalam Menangani Permasalahan Sampah. Publikasi Online. http://download.portalgaruda.org/article.php, retrieved on March 30, 2017.

4. Kim, H., Adisak, S., Seewo, M.S., and Pakkapong, P. 2016. Participation in Household Garbage Sorting of Baan Lao Yai Community, Kudchum District, Yasothon Province. International Journal of Agricultural Technology, Vol. 12 No. 5. Pp:827-840.

5. Maulina, A.S. 2012. Identifikasi Partisipasi Masyarakat Dalam Pemilahan Sampah Di Kecamatan Cimahi Utara Serta Faktor Yang Mempengaruhinya. Jurnal Perencanaan Wilayah dan Kota, Vol. 23 No. 3, pp: $177-196$.

6. Mombo, F. \& Birgiwa, D. 2017. The Role of Sub-Saharan Africa Countries' Households Waste Charges on Sustainable Cities Development. Int J Waste Resour, Vol. 7 No. 1, pp:1-6.

7. Notoatmodjo, S. 2010. Ilmu Kesehatan Masyarakat, Jakarta: Rineka Cipta.

8. Posmaningsih, D.A.A. 2016. Faktor-Faktor Yang Mempengaruhi Partisipasi Masyarakat Dalam Pengelolaan Sampah Padat di Denpasar Timur. Jurnal Skala Husada, Vol. 13, No. 1, April 2016. Pp: 59-71.

9. Ratiabriani, N.M. \& Purbadharmadja, I.B.P. 2016. Partisipasi Masyarakat dalam Program Bank Sampah: Model Logit. Jurnal Ekonomi Kuantitatif Terapan ,Vol. 9 No. 1, pp: 53-58.

10. Slamet, J.S. 2009. Kesehatan Lingkungan. Yogyakarta: Gadjah Mada University Press.

11. Suyono, B. 2010. Ilmu Kesehatan Masyarakat dalam Konteks Kesehatan Lingkungan. Jakarta: EGC

12. Suyanto, E. 2015. Model Partisipasi Green Community Dalam Perumusan Kebijakan Green Waste Lintas Rumah Tangga Mendukung Kota Hijau Purwokerto. IPB, Bogor.

13. Tanuwijaya, F. 2016. Partisipasi Masyarakat Dalam Pengelolaan Sampah di Bank Sampah Pitoe Jambangan Kota Surabaya, Jurnal Kebijakan Manajemen dan Publik, Vol. 4, No. 2, Mei-Agustus 2016. Pp: 230-244.

14. Tulit, B.M., Arjana, I.G.B., Ramang, R. 2014. Pengaruh Faktor-Faktor Sosial-Ekonomi Terhadap perilaku Pengelolaan Sampah Domestik Di Nusa Tenggara Timur. Jurnal IImu Lingkungan, Vol. 12 No. 2, pp: 105-117. 